\title{
OBSERVATIONS ON WOOD-BORING INSECTS, THEIR PARASITES AND OTHER ASSOCIATED INSECTS. ${ }^{1}$
}

\section{By Charles T. Brues}

During the course of many years' interest in the several groups of Parasitic Hymenoptera the writer has frequently been struck by the preponderance of primitive types which prey upon wood-boring insects. Not only this, but several of the most primitive families of phytophagous Hymenoptera develop mainly within the tissues of woody plants and an exceptionally large proportion of the leaf-feeding sawflies subsist upon the foliage of trees. These facts suggest that the early phylogenetic history of the Hymenoptera was in some way bound up in the deveopment of the woody flora and that this early association has persisted to the present time without sufficient change to destroy the earmarks of past history in the modern hymenopterous fauna.

The immediate occasion for the present discussion is a small, but quite varied collection of insects made during the past summer at my summer home in Petersham, Mass. Early in the season the attention of my wife was attracted by a considerable number of flying insects that had congregated upon the panes of a window in a room where the stove wood for the household is stored. This room contains an assortment of wood of various sizes and varieties, principally oak, chestnut, white pine, red maple and birch. The wood is cut in the nearby woodlot one year, allowed to season and then sawed, split and stored away the next year. Before storage, it has therefore an opportunity to be attacked by various wood boring insects and fungi together with the insects that are attracted to the latter.

So many specimens appeared on the first day that collections were made daily upon the window from early July to late September and by the end of the season we had amassed a considerable collection. After sorting and identification, the fol-

${ }^{1}$ Contribution from the Entomological Laboratory of the Bussey Institution, Harvard University, No. 275.) 
lowing list was compiled which includes practically all of the species taken.

\section{Coleoptera}

Nearly all of the members of this order have been identified by one of my students, Mr. P. J. Darlington, Jr.

\section{Family Rhipiphoridae}

Pelecotoma flavipes Melsh. Twenty-one specmens of both sexes of this rare species, July 13-28. This has been reported emerging from beech wood, but the present specimens came from that of some other tree, probably red maple. The habits of the larvæ appear to be unknown, although the genus is undoubtedly parasitic.

\section{Family Pyrochroidae}

Dendroides bicolor Newm. Three males July 13 and 18. This species breeds commonly in various deciduous trees such as oak, maple, beech and birch

Dendroides concolor Newm. One female July 13. This species is known to feed upon the same trees as the foregoing.

\section{Family Elaterida}

Melanotus trapezoideus Lec. One specimen, July 20.

Melanotus pertinax Say. One specimen, July 13. Members of this genus are commonly taken beneath the bark of various trees.

\section{Family Melasidae (Eucnemidø)}

Isorhipis ruficornis Say. 245 specimens representing both sexes in the proportion of 127 males to 118 females. This species was the most abundant insect in the present collection. It was taken first on July 13 and was still appearing when the last collections were made late in September although present in greatest numbers late in July. The species has been found in beech and soft maple and most if not all of the present series emerged from red maple. 


\section{Family Buprestidoe}

Dicerca lurida Fabr. One specimen, July 13. This species breeds commonly in hickory, although the present one came probably from an oak log.

Chrysobothris femorata Oliv. One specimen, July 13. This is a common enemy of apple, but the larvæ occur in several other deciduous trees.

\section{Family Dascyllida}

Eucinetus morio Lec. One specimen, July 20. This has been taken beneath oak-bark and on fungi on oak.

\section{Family Dermestidce}

Attagenus piceus Oliv. Two specimens, July 26-28. This is the well known "carpet beetle" which develops in woolen materials, feathers and other articles of animal origin. Weiss and West (Proc. Biol. Soc. Washington, vol. 33, p. 6 1920) record it from a fungus Lenzites betulinus so that its occurrence in the present series is probably not accidental. In country houses the larvæ find food in the many flies and other insects that enter the walls, window casings, etc. for hibernation, many of them to die before the advent of spring.

\section{Family Ostomatidce (Trogositido)}

Thymalus marginicollis Chev. Two specimens, July 20. This species breeds in the common shelf-fungus of birch, Polyporus betulinus.

\section{Family Nitidulidoe}

Epurcea sp. One specimen. The members of this genus feed on fungi.

\section{Family Mycetophagidee}

Mycetophagus flexuosus Say. One specimen, August 23. A common fungus-beetle. 


\section{Family Endomychidae}

Endomychus biguttatus Say. One specimen, August 23. This is another fungus-beetle.

\section{Family Tenebrionidoe}

Diaperis maculata Oliv. One specimen of this abundant species which occurs in fungi, especially in the shelf-fungus of birch.

Upis ceramboides Linn. One specimen, August 8. This is a northern beetle with circumpolar distribution; it occurs under the bark of logs of various kinds.

\section{Family Melandryidoe}

Synchroa punctata Newm. Six specimens, July 13 to 20. This species occurs under the bark of various trees, particularly pine and maple.

\section{Family Anobiidoe}

Hadrobregmus carinatus Say. Eleven specimens, July 1317. This species breeds commonly in maple logs and more rarely in those of other trees, such as beech.

Ptilinus ruficornis Say. 18 specimens, July 13-20. This small beetle has been bred from dead branches and logs of various deciduous trees.

\section{Family Cerambycidoe.}

Thirteen species of this large family were collected. Practically without exception all members of the group are woodborers.

Hypermallus villosus Fabr. One specimen, July 19. This is the common "twig-pruner" of oak which occurs occasionally in maple also.

Brachyleptura rubrica Say. One specimen, July 20. The host tree of this tree has apparently never been recorded. It probably occurs in oak. 
Brachyleptura canadensis Fabr. One specimen, August 8. The larva develops in the wood of several conifers.

Phymatodes testaceus Linn. One specimen, July 13. The larvæ occur in oak and are commonly bred from cord-wood.

Xylotrechus colonus Fabr. Seven specimens, July 13 to September 26. This is a common species, usually bred from oak but found less abundantly in logs of other deciduous trees.

Xylotrechus undulatus fuscus Kirby. One specimen, August 18. This occurs in the wood of conifers.

Neoclytus acuminatus Fabr. Eight specimens, July 17 to September 26. This is an abundant species which develops in a great variety of deciduous trees.

Anthoboscus ruricola Oliv. Five specimens, July 13-18. This is known to feed in hickory and elm; these specimens may have come from the latter.

Monochamus scutellatus Say. One specimen, July 19. This is an abundant species in New England feeding in white pine logs which are soon ruined if allowed to remain unsawed during the warmer part of the year.

Microgoes oculatus Lec. One specimen, July 19. The larva bores in oak and hickory.

Lepturges querci Fitch. One specimen, July 20. This small form develops in the wood of oak, hickory and other trees. Hyperplatys maculata Hald. Three specimens, July 14 to 20. The larvæ develop in oak and the wood of other deciduous trees.

Urugraphis fasciata. Two specimens, July 19. The larvæ of this species feed commonly in the bark of oak, but occur also in that of other deciduous trees and even in pine.

\section{Family Platystomatidae}

Euparius marmoreus Oliv. Two specimens, August 23 and September 26. This is a fungus-beetle.

Choragus zimmermanni Lec. One specimen, July 28. This is a wood-boring species that has been bred from sweet-gum, but which must have other hosts. 
Corrodentia

Family Psocidae

The four species listed below were examined and named for me by Mr. Nathan Banks.

Psocus leidyi Aaron, two specimens.

Psocus variabilis Aaron, two specimens.

Myopsocus sparsus Hagen, seven specimens.

Peripsocus permadidus Walsh, one specimen.

The members of this interesting group are said to feed mainly upon lichens and fungi and many species are consequently associated with trees and old wood.

\section{Thysanoptera}

Two species were taken which have been very kindly identified by Dr. J. D. Hood.

\section{Family Phloothripidae}

Hoplothrips karnyi major Hood, two females, July 20 and 26. Trichothrips sp. One male, July 20. This is probably an undescribed species known to Dr. Hood from Illinois also.

\section{HYMENOPTERA}

\section{Family Xiphydriidøe}

Xiphydria maculata Say. 147 specimens of both sexes, July 13 to September 26. The great majority of the specimens emerged during the third week in July. The females are extremely variable in size ranging from 8 to $20 \mathrm{~mm}$. in length while the males range from $7-12 \mathrm{~mm}$. This species is known to breed in maple and most if not all the individuals in the present series emerged from red maple logs.

Species of Xiphydria are commonly parasitized by members of the Aulacid genus Pammegischia of which two species were obtained as noted on another page, without question from this wood-wasp. 


\section{Family Aulacidoe}

Pammegischia pallipes Cresson. Four females and a male, July 13 and 17 . The abdomen of two females is black, except the first and second segments; and the others agree with the description given by Bradley ('08) of $P$. xiphydrio Ashm. The male taken with them is typical of $P$. pallipes and Bradley is undoubtedly right in regarding these two as sexes of the same species. $P$. xiphydrioe has been bred from Xiphydria provancheri living in birch twigs according to Viereck and Champlain reared $P$. burquei Prov. from another species of Xiphydria.

Pristaulacus stigmaterus Say. Two females and one male, July 13 and 16.

Gasteruption tarsatorium Say. Two females, July 13 and 17.

Gasteruption incertum Cresson. Two females and two males, July 13 and 17.

\section{Family Braconidae}

Spathius simillimus Ashmead. One female, July 17. This species has been bred from the small Buprestid beetle, Agrilus bilineatus, a well known enemy of chestnut and oak. The members of the genus are parasites of small wood-boring beetles, principally bark-beetles of the family Ipidæ.

Helcon ligator Say. Three females and one male, July 13 and 19. This has been bred from several Cerambycidæ, including Neoclytus acuminatus Fabr. which is abundant in the present collection.

Blacus longicaudis Prov. Five specimens of both sexes, July 18-September 5 .

Ascogaster carpocapse Viereck. One male, July 13.

This species, described by Viereck as a Chelonus was bred from the codling moth Cydia (Carpocapsa) pomonella and has since been reared by Wilcox (Psyche, vol. 25, p. 17, 1918) from the Oriental moth (Cnidocampa flavescens).

Apanteles consimilis Viereck. Seventeen females and two males, July 14-Aug. 23. According to Muesebeck this is not a common species, or at least has been only rarely taken. 


\section{Family Ichneumonidoe}

Rhyssa canadensis Provancher. Three females, September 27. As members of this genus are known to parasitize Xiphydria, these probably came from the abundant $X$. maculata.

Arotes amœnus Cresson. Two females, July 13. Species of Arotes are parasites of cerambycid beetles.

Lissonota insita Cresson. Nine specimens of both sexes, July 13-August 22.

Polysphincta texana Cresson. This is a widely distributed parasite of spiders that has been bred by Cushman from the common Steatoda borealis.

\section{Family Vanhorniidae}

Vanhornia eucnemidarum Crawford. Thirteen females and seven males, July 13-September 26, all but one taken during July.

This most remarkable insect was made the type of a new family by Crawford in 1909 when he first described it. The types were bred by Van Horn from larval cells of an unidentified Melasid (Eucnemid) beetle and the species has since been recorded by Champlain (Psyche, vol. 29, p. 100, 1923) as a parasite of Isorhipis flavicornis. The present series are undoubtedly from the same host, which is abundantly represented in the collection at hand.

Crawford makes no reference to the systematic relationships of Vanhornia except to note that the wing-venation resembles that of Helorus. On account of its exodont mandibles one would naturally compare it with the family Alysidæ and the somewhat dubious insect, Lysiognatha, placed by Ashmead as an Alysiid. It is very evident, however, from the other characters that Vanhornia has no affinities with any Alysiid. The antennæ are not multiarticulate and the wing is provided with a costal cell, both of which are fundamental differences. Also the structure of the abdomen which is heavily chitinized below, and forms a carapace above is entirely dissimilar to that of any Alysiid although in one genus, Symphya of the latter family the tergites 
are fused. This similarity is however purely superficial. Considering the wide divergence between the two groups we must conclude that the reversed mandibles are of independent origin and that this peculiarity has developed more than once in the order Hymenoptera.

The similarity in venation between Vanhornia and Helorus is very great and in fact there is no difference except that Helorus has lost the upper section of the basal vein which is still present though weak in Vanhornia. Ashmead speaks of the basal vein as bent down to form a discoidal cell in Helorus but this vein is a combination of the lower section of the basal and the first section of the cubitus which form together an arc as is readily seen by comparison with Vanhornia or Ropronia. Ropronia was placed by Ashmead as a part of the family Heloridæ and I think correctly so although Bradley has disputed this. Ropronia again agrees closely with both Helorus and Vanhornia in venation. Aside from the peculiarities of the head associated with the greatly enlarged mandibles, the complete reduction of the abdominal petiole and the greatly developed ovipositor, Vanhornia is clearly similar to Helorus and the Jurassic genus Mesohelorus and the two families must be placed near together in the group Serphoidea. Handlirsch following Viereck has placed Vanhornia next to the Alysiidæ and the strange genus Gnathobracon. This position appears to be clearly untenable as noted above.

\section{Family Chrysididoe}

Chrysis verticalis Patton. One female, September 26.

Omalus iridescens Norton. Four specimens, July 17-26. Species of Omalus are parasitic upon wasps that nest in wood $O$. corruscans has been bred from Stigmus americanus which is probably the host of the present specimens.

\section{Family Eumenida}

Odynerus cristatus Saussure. Nine specimens, July 18-28. This is a common species nesting in burrows in wood. 


\section{Family Crabronidoe}

Solenius (Crabro) interruptus Lepeletier. One specimen, July 17. Nests in wood.

Blepharipus nigricornis Provancher. Five specimens, doubtfully of this species, July 17-September 26 . This nests in wood also.

\section{Family Trypoxylonidoe}

Trypoxylon frigidum Smith. One specimen, July 18. Nests in wood.

\section{Family Pemphredonidoe}

Pemphredon tenax Fox. Two specimens, probably this species, July 26.

Pemphredon angularis Fox. One specimen, September 26.

Stigmus americanus Packard. Two specimens, September 26.

Passaloecus annulatus Say. Four specimens, July 20-26. This and the preceding three species all build their nests in wood.

\section{Family Hylaidae}

Hylaeus (Prosopis) modestus Say. Two specimens, July 18August 8.

\section{Family Megachilidoe}

Megachile relativa Cresson. One specimen July 17. This and the preceding bee nest in wood.

\section{Diptera}

Sixteen species were collected, distributed in a number of families. My friend, Professor A. L. Melander, has been so good as to identify all of these except the Phoridæ.

\section{Family Itonidida}

One specimen, July 16. Not in good enough condition for more accurate determination, but probably a xylophagous form. 


\section{Family Mycetophilidoe}

Sciara $s p$. One specimen, July 17 . Some species of this genus are mycetophagous, developing in fleshy fungi.

\section{Family Chironomidoe}

Culicoides sp. One specimen, July 16. Accidental; this is a phlebotomic type with aquatic larva.

\section{Family Scatopsido}

Reichertella femoralis Meigen. One specimen, July 17.

\section{Family Scenopinidae}

Scenopinus fenestralis Linne. Three specimens, July 20-28, September 26. This is the common "window-fly" frequently seen in houses. The larva is carnivorous and has been reared from the preparatory stages of the clothes-mot .

\section{Family Phorida}

Aphiochceta pulicaria Fallen. Eight specimens of both sexes, July 14-August 23.

A phiochreta agarici Lintner. One female, July 17 . The larvæ live in various fleshy fungi.

Aphiochota sp. One female, July 28. This is probably an undescribed species with swollen, heavily chitinized proboscis.

A phiochoeta sp. Eight specimens, July 18-August 23. Similar to $A$. iroquoiana Malloch, but probably an undescribed species.

\section{Family Muscida}

Muscina stabulans Linn. Two specimens, August 8. The larvæ of this fly are predatory upon other dipterous larvæ.

\section{Family Trypetide}

Pseudotephritis vau Say. Two specimens, July 23 and August 23. The larvæ occur beneath bark. 


\section{Family Oscinida}

Oscinis nitidissima Meigen. One specimen, July 17. The larvæ of Oscinis develop in the stalks and roots of various plants, particularly grasses.

\section{Family Drosophilidae}

Drosophila quinaria Loew. Two specimens, July 20 and August 22. The larvæ have been found in fruit, but the species may also develop in fungi.

Drospohila affinis Sturtevant. One specimen, July 26. Sturtevant has bred this species from fruit and has found the adults attracted to exuding sap.

Drosophila sp. One specimen, July 26.

\section{Hemiptera}

\section{Family Mirida}

The two species were kindy identified by Professor H. H. Knight.

Plagiognathus politus Uhler. One specimen, July 18. This leaf-bug feeds on various plants, including apple foliage.

Pilophorus uhleri Knight. One specimen, July 28.

\section{Family Anthocoride}

Xylocoris cursitans Fall. One specimen, kindly identified by Professor H. M. Parshley.

\section{Family Reduviida}

Reduvius personatus Linn. One specimen, July 14. This is a predatory species, often found beneath loose bark where it feeds upon other insects.

HoMOPTERA

F amily Aphidida

Melanoxantherium medium Baker. A few specimens of aphids were seen and one taken on July 16th proves to belong to this species which occurs on poplar. 


\section{Conclusions.}

The size of the present collection is of course very small but it allows one to draw several conclusions relating to the composition of the insect fauna that is associated with the wood of dead trees; conclusions, it may be added, which are substantiated and supplemented in detail by the vast array of accumulated literature relating to forest insects.

a) In the first place, there are many species, particularly Coleoptera and phytophagous Hymenoptera which develop directly in the wood or beneath the bark of logs.

b) Among the parasitic Hymenoptera there is a series of species which prey upon these xylophagous beetles and other Hymenoptera. Very similar to these are certain predatory forms, especially beetles which depend upon particular host species for food.

c) There are further many mycetophagous species, mainly beetles, which develop in the several types of fungi regularly associated with decaying wood. These likewise support a series of parasitic forms.

These three ethological groups we may regard as constituting a primitive fauna which has long been characteristic of wood. A small proportion occur in living trees, but such a great majority live in the wood of moribund or dead trees that we must believe the latter habitat to present the most primitive one. In the case of the mycetophagous types this is still more evident.

d) A secondary fauna includes first a number of predatory insects which are not like the parasites and predators previously referred to, associated with particular hosts, but find simply a convenient source of food supply in the xylophagous fauna.

e) Other members of the secondary fauna include various insects, such as wasps and bees that find suitable nesting sites in burrows in the wood. Although such habits are firmly fixed in one or two families, they are clearly not of primary general significance.

f) Finally, as in any biocœnose there are forms on the borderland whose occurrence is either wholly chance, or at least very occasional and due to sporadic combinations of circums- 
tances that do not occur with sufficient regularity to support species unable to breed elsewhere. An example of this condition is seen in the species Drosophila listed above which breed under bark only where the latter is wet and fermenting due to the presence of yeasts.

Three of the more extensive orders of holometabolous insects, the Coleoptera, Hymenoptera and Lepidoptera are very generally associated with trees although by no means exclusively so. This is particularly true of the Coleoptera which is of the three without question the oldest from a geological standpoint. As was hinted at the outset it seems quite apparent that the Hymenopterous fauna gives evidence of long association with trees and as will be shown in a moment the same appears to be true of the other orders. This implies a rather lasting and unchanging environment.

Contributory to a continuity of fauna is the uniformity of conditions within the woody tissue. The material composition of the wood and bark varies only to a very limited extent and these offer the same food materials, supplied with water in far more constant proportions than food materials that are temporarily or permanently affected by drought or superabundant moisture. Aside from climatic changes and seasonal fluctuations the temperature variations of such an environment are of quite different order from those to be encountered in the course of a free and active existence in the open. In all, the conditions of life in wood are conducive to conservatism as they offer few incentives for progressive adaptations. There is no question that these facts have had a profound influence upon the rapidity of evolution of the insects concerned. Consequently, we find at the present day many primitive types persisting as relicts of an earlier xylophagous fauna still associated with woody tissue and still retaining a primitive series of parasitic enemies, at least among the Hymenoptera. With this fauna are other insects that have adopted this habitat more recently and some of these very patently represent acquisitions derived from other habitats.

These points may be readily clarified by the citation of examples taken from several orders of insects. Indeed, a very representative series might be drawn from the present small col- 
lection without having recourse to other well known instances. Among the several extensive and diversified modern orders of insects, including the Coleoptera, Lepidoptera, Hymenoptera and Diptera, all of which are traceable to an origin from an earlier Mecopteroid type the occurrence of dendrophily is well marked in several of the primitive families. Among the Trichoptera wood-boring larvæ are of rare occurrence, no doubt by reason of the fact that the developmental stages are almost without exception aquatic. However, in the other orders there are numerous and widely scattered examples of xylophagous habits, and with the exception of the Coleoptera, the woodboring forms are mainly members of the more primitive families. A reason for the general absence of the more primitive beetles in this habitat is not far to seek since this group is the oldest of the series. It is represented by several types in the Upper Permian and in the Upper Trias had become quite prevalent, so that if the association of beetles with trees dates from this time or later there were various types of Coleoptera extant. The oldest Hymenoptera known have been found in the Upper Jurassic and are very similiar to living members of the archaic family Siricidæ ${ }^{1}$ Whether the order existed in the Upper Permain appears very doubtful, as the only insects so far discovered which appear to be in any way related to the modern Hymenoptera are the order Protohomoptera found by Tillyard in the Upper Permian of Kansas. Insects supposed to be Lepidoptera have been reported from the Middle Jurassic but these have been shown without question to be Homoptera, so that no Lepidoptera are actually known earlier than the Tertiary. This is obviously due to incomplete knowledge and to judge from their food relations at the present time as outlined in the present acoount, it seems probable that the Lepidoptera were present in the Liassic and probably in the Triassic. This order is thus apparently older than the Hymenoptera but of more recent origin than the Coleoptera. The Diptera are well represented in the Upper Liassic,

${ }^{1}$ Since the above was written I have received a paper by Martynov (Bull. Acad. Sci. Russie, vol. 19, 1924) in which several remarkable Hymenoptera are described from Jurassic deposits in Turkestan. These include a very primitive type of sawfly, an oryssid-like genus and a member of the family Heloridæ. These discoveries offer strong confirmation of the views expressed in the present paper. 
but only by clearly primitive nematocerous types (except for one typical Xylophagid). We may therefore safely conclude that this order had its origin after the Permian in the Liassic.

With these facts in mind, as gleaned from the paleontological data so far accumulated, we may inquire more in detailconcerning the occurrence and distribution of xylophagous habits in these several orders.

In the Lepidoptera there are several very generalized families which form the suborder Homoneura. Of these the small but widely distributed family Hepialidæ includes large moths most of which develop in burrows that they excavate in wood, while others are subterranean and feed upon the roots of trees. Although not entirely lignivorous, it is interesting to note that the most primitive of all families belonging to the Homoneura, the Micropterygidæ includes species that mine in the leaves of trees as well as forms that feed upon more primitive plants such as mosses and liverworts.

Another primitive family, the Cossidæ, includes large moths which are xylophagous as larvæ, and as typified by members like the Leopard Moth (Zeuzera) and Carpenter Moth (Prionoxystus) are notoriously destructive to certain deciduous trees. Likewise the related family Sesiidæ (Aegeriidæ) restrict their diet to the wood of trees except in rare instances where a few species have become secondarily associated with herbaceous plants. These several families are all internal feeders and true woodborers, but even in the case of one family which feeds on foliage, the leaf-rolling Tortricidæ, the selection of trees rather than herbaceous plants is very marked. Another series which exhibits the same predilection for trees is the enormous family Geometridæ. These are however not so important from the present standpoint,for although quite generalized they are by no means so primitive as the other families mentioned.

Among the Hymenoptera the case is still clearer for the most primitive groups not only of phytophagous types but of parasitic ones as well are definitely associated with the woody flora. There is some ground for a difference of opinion in selecting the most primitive living type of Hymenoptera and also in indicating the probably phylogeny of the lower groups. On the 
basis of wing venation and many anatomical structures it seems probable that the families Xyelidæ and Pamphiliidæ represent the most primitive type related to forms from which the presentday Sawflies (Tenthredinidæet al.) have been derived. They as well as the sawflies are typically associated with trees although they are leaf-feeders and notxylophagous. From them also probably have come the wood-wasps, typified by the very generalized Xiphydriidæ and the Siricidæ. From a paleontological standpoint the Siricidæ might appear to be the oldest Hymenoptera as the only clearly preserved members of the order known before the Tertiary are some upper Jurassic Siricidæ that occur in the Solenhofen lithographic stone. ${ }^{1}$ This is very scant evidence, however, and indicates only a lack of knowledge as the early Tertiary, especially the Lower Oligocene sees the Hymenoptera as diversified and almost as modern in type as at the present day. Nevertheless, the Siricidæ clearly represent the remnants or offshoot of a group which gave rise to an important and extensive series, the Parasitic Hymenoptera, which include a considerable number of families and a vast number of genera and species. The parasitic habit is first manifest in the entomophagous Oryssidæ and in them we find still an association with wood boring insects, as Oryssus is known regularly to live in wood and has recently been found to be an ectoparasite of beetles belonging to the family Buprestidæ. The Oryssidæ have been considered as forming an independent superfamily, but most hymenopterists agree in associating them with the Siricidæ. There can be no reasonable doubt that they have arisen from the siricoid stem, as well as that they represent the most primitive parasitic group in the order. Among the other parasitic $\mathrm{Hy}$ menoptera, the Aulacidæ (exclusive of Evania and its allies) show a number of similarities to the Oryssidæ of such nature that we must consider them related, and as the Aulacidæ are the most primitive of the Ichneumonoidea we find this vast group clearly brought forth by xylophagous ancestors. The only other group of Icheneumon-flies that retains the costal cell which disappears in the higher forms, is the Stephanidæ. Little is known of their habits, but their association with trees leaves

${ }^{1}$ See footnote on page 87 . 
little doubt that they are parasites of wood-boring insects. The same is true of the peculiar family Megalyridæ known only from Australia and South America and representing an archaic type most likely another derivative of the Siricoids. Among the two dominant present day families of ichneumon-flies, the Ichneumonidæ and Braconidæ we find the more primitive smaller groups of each to be parasites of wood-boring insects, e. g. the Rhyssini of the former family and the Spathiinæ, Hormiinæ and Helconinæ of the latter. Several other families have similar habits but these are much more highly specialized types, except perhaps the remarkable genus Ibalia. This is usually considered to be an aberrant Cynipid but it shows affinities with the Siricidæ, upon which it is parasitic, and is without question a relict of some primitive group.

From the foregoing it is evident that the association of the orders Hymenoptera and Lepidoptera with trees, especially with the wood of the latter is clearly marked in the most primitive families, in fact we may be almost satisfied without further evidence that these two large and diversified orders arose as lignivorous forms. This can hardly be true of their earlier ancestral type, the Mecoptera, nor of the more primitive Mecopteroid derivatives, the Trichoptera. This forms strong contributory evidence that the Hymenoptera and Lepidoptera had an origin coincident with that of the modern ligneous flora. The origin of the Coleoptera at an earlier time before this flora had developed resulted not in an association of the more primitive adephagous beetles with trees, but in the appearance of the lignivorous habit in some of the most highly specialized Celeoptera such as the Cerambycidæ and Ipidæ (Scolytidæ). Some other families like the Buprestidæ have similar habits, but they represent by no means the most generalized members of the order. With the Diptera the rather sparse occurrence of wood boring forms offers little suggestion that the earlier types may have been associated with trees. Obviously the degenerate mouthparts of the larval dipteron are not well suited to chewing wood, even in the more primitive nematocerous forms and only occasional types have become dependent upon the woody flora. 

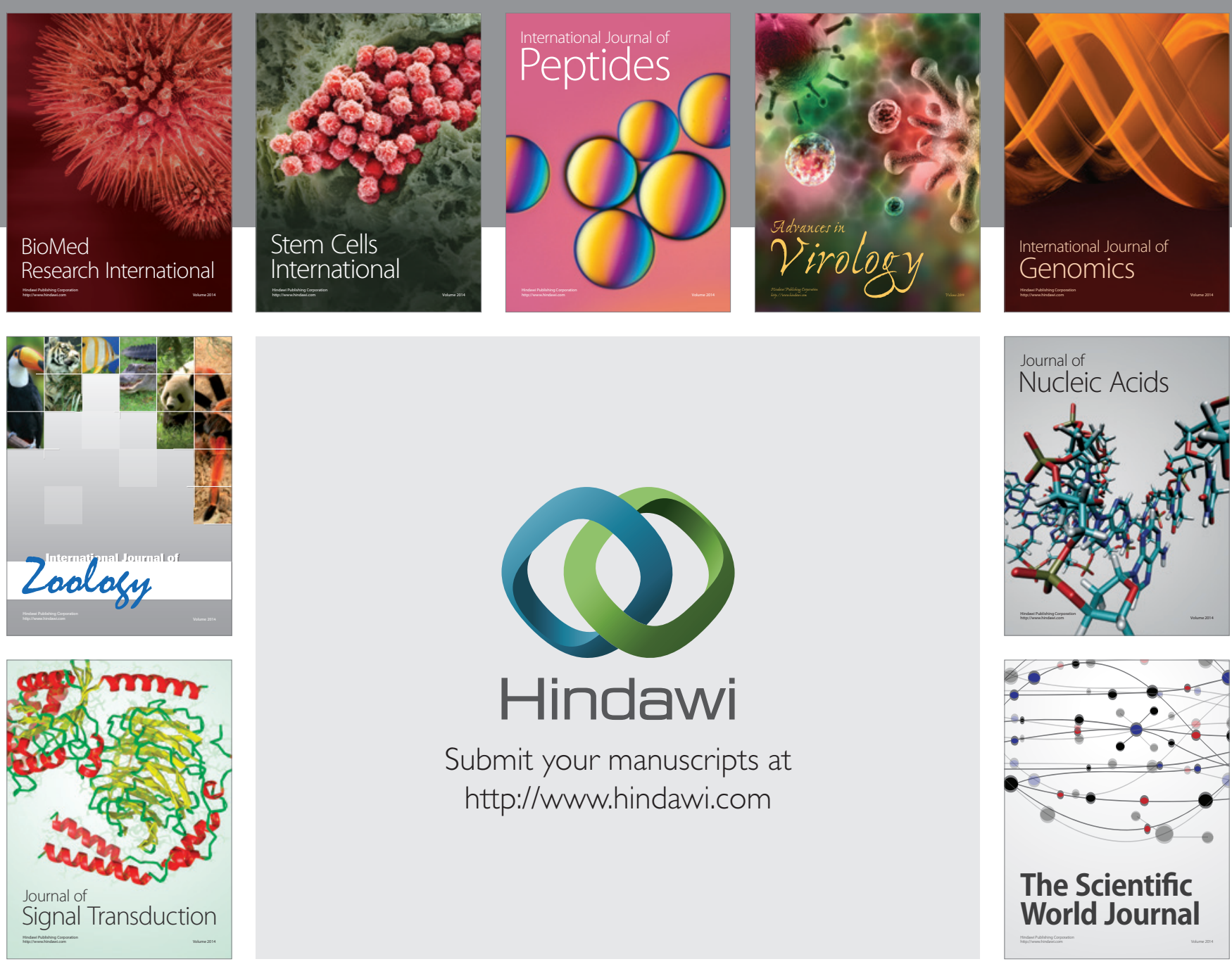

Submit your manuscripts at

http://www.hindawi.com
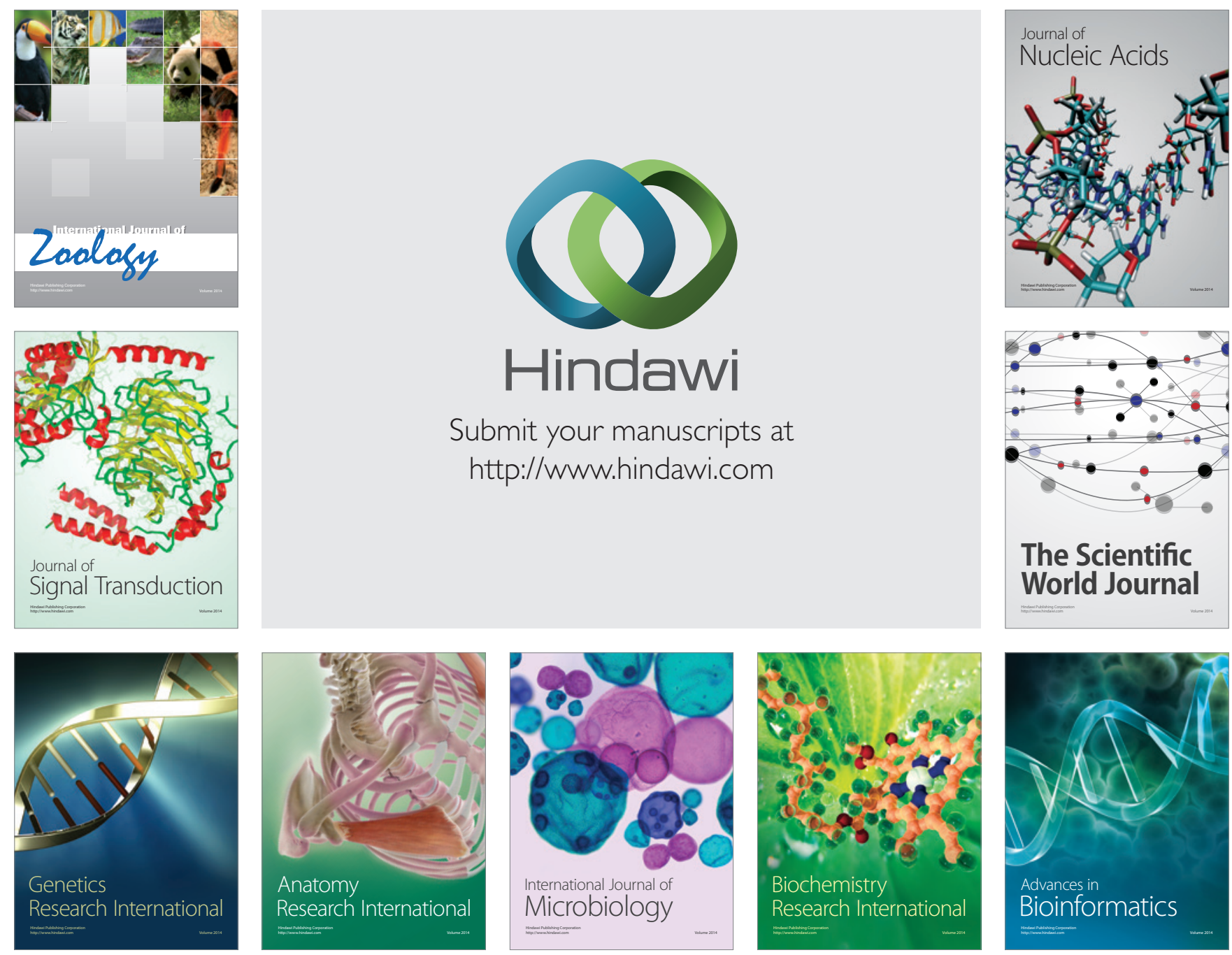

The Scientific World Journal
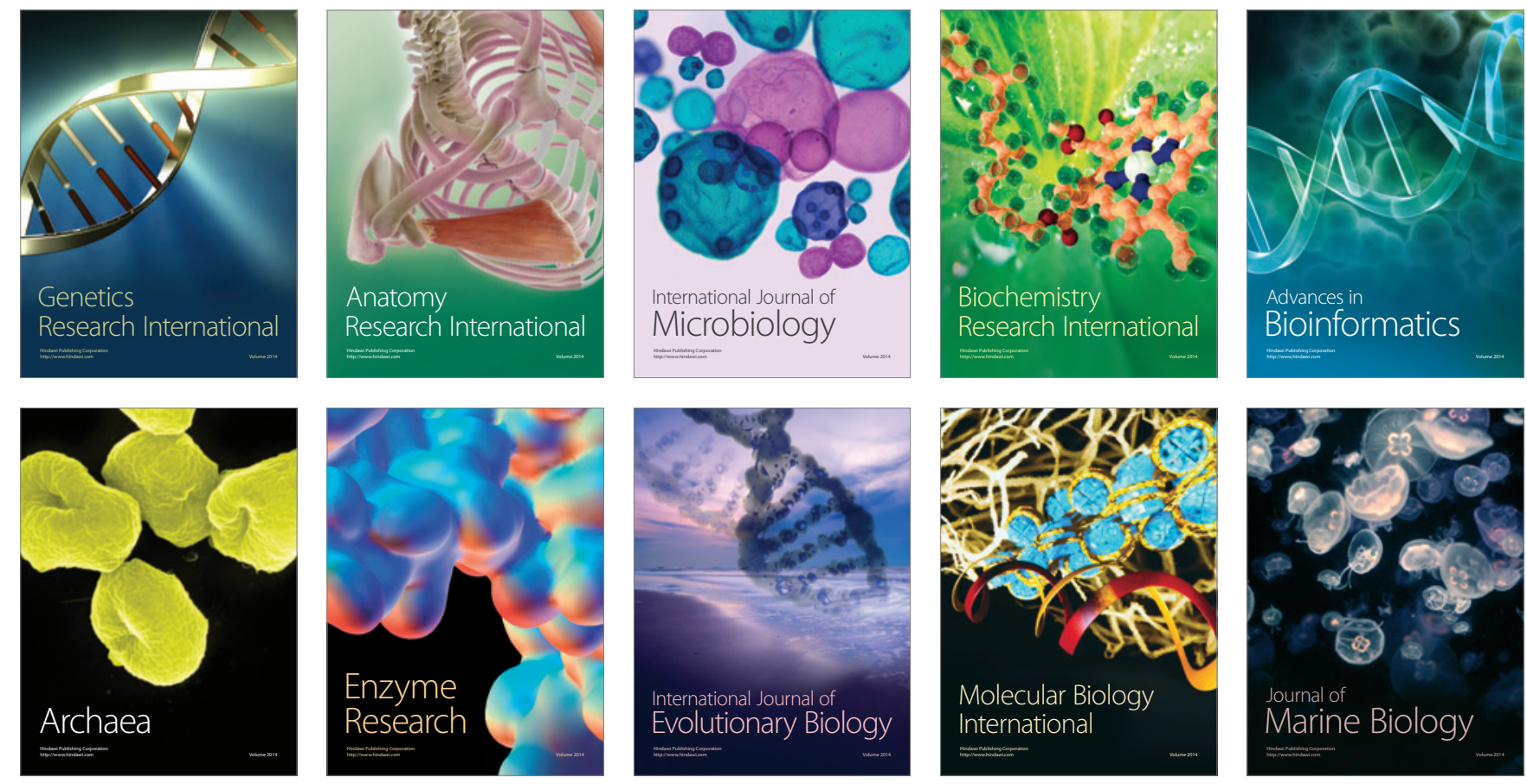